\title{
Long-term preservation of cells and tissues: a review
}

\author{
DAVID E. PEGG \\ From the Division of Cryobiology, Clinical Research Centre, Watford Road, Harrow, Middlesex HAI $3 U J$
}

There has been a steady growth of interest in cryobiology during the past 10 years: this decade has seen a considerable increase in our understanding of the effects of low temperatures and of freezing on living cells and a significant development of new and more refined methods of overcoming freezing injury in order to achieve viable storage at very low subzero temperatures. This has led to workers in many fields realizing, for the first time, that cryobiology may be able to provide them with useful tools for their own purposes. Pathology is no exception. One of the very first cell types to be preserved at very low temperatures was the erythrocyte, and much of the subsequent theoretical work in cryobiology has used this simple cell as a model system. As a result, a whole range of red cell preservation techniques has been evolved, some applicable to clinical transfusion and others more suited to the laboratory. The haematologist may also wish to store lymphocytes, thrombocytes, haemopoietic cells, and possibly granulocytes. Microbiologists need to preserve microorganisms for reference purposes, and also tissue culture cells and fetal tissues for virus isolation. Finally, experimental pathologists may wish to preserve a whole range of tissues for their studies, skin and endocrine tissues, for example.

In this review I propose first to outline our present understanding of the mechanisms of freezing injury and cryoprotection and then to deal with practical methods of long-term storage that have been developed for use in haematology and microbiology. Finally, I shall deal more generally with the development of preservation techniques for some more complex tissues that might find some relevance in experimental pathology. I have quite arbitrarily defined 'long-term' to mean 'longer than one month' for the purpose of this review.

\section{Cooling of Cells to Temperatures above $0^{\circ} \mathrm{C}$}

The use of cooling to prolong the survival of isolated cells and tissues depends on the effect that a reduction in temperature has on chemical reaction

Received for publication 18 December 1975 rates and hence on metabolism, thereby reducing the demand for oxygen and substrates. Unfortunately, however, cooling to temperatures above $0^{\circ} \mathrm{C}$ does not provide adequate storage periods for many practical purposes, and there are no common cells for which long-term preservation can be obtained in this way. There are many reasons why this is so: metabolism does not cease at $0^{\circ} \mathrm{C}$, nor are all reactions slowed to the same degree; consequently, inter-related metabolic pathways may be 'dislocated' by cooling. Some effects of cooling are frankly harmful: for example, cooling switches off the Na-pump, which is responsible for the regulation of cell volume, and as a result cooled cells swell (Leaf, 1959); membrane lipids undergo phase changes which may in themselves be harmful, and which also have dramatic effects on the reaction rates of membrane-bound enzymes (Lyons, 1972); poorly soluble materials may precipitate, and dissociation constants change, resulting in changes in the composition and $\mathrm{pH}$ of solutions (van den Berg, 1959; van den Berg and Rose, 1959); some cells are damaged or even killed by a reduction in temperature per se, especially if cooling is rapid, a phenomenon known as thermal shock (Lovelock, 1955). Taken together the various changes that are induced by cooling severely limit the time for which cells can be stored at temperatures above $0^{\circ} \mathrm{C}$, but when attempts are made to use lower temperatures, freezing occurs, and freezing itself is normally lethal to cells.

\section{Freezing}

Freezing is the separation of pure water as ice, which concentrates any solutes present in the remaining liquid phase. This raises the possibility of two sources of freezing injury, ice itself and the altered liquid phase. Let us look first at the changes that occur in the liquid phase.

The principal solute in biological fluids is sodium chloride. When isotonic $(0 \cdot 15 \mathrm{M})$ sodium chloride solution is cooled it may supercool a few degrees, but if seeded it freezes at $-0.56^{\circ} \mathrm{C}$. As cooling is continued, so further ice separates, sufficient at each temperature to concentrate the salt in the 
remaining liquid to produce a solution that has that freezing point. Thus, the remaining solution is progressively diminished in volume and increased in strength until at $-21 \cdot 1^{\circ} \mathrm{C}$ the saline has reached a concentration of $5.2 \mathrm{M}$; at this temperature, the eutectic point, the remaining solution solidifies. Therefore, when cells are suspended in isotonic saline that is frozen, they are subjected to a 32-fold increase in sodium chloride concentration. In the mixed solute systems that occur in practice, similar changes in osmolality occur, but in addition there are changes in composition brought about by differing solubility characteristics of the various solutes. This may be very important; for example, van den Berg (1959) and van den Berg and Rose (1959) have shown that when a solution containing $\mathrm{NaH}_{2} \mathrm{PO}_{4}$ and $\mathrm{Na}_{2} \mathrm{HPO}_{4}$ is cooled, its $\mathrm{pH}$ falls if the molecular ratio of the two compounds is less than 57 , but the actual $\mathrm{pH}$ is greatly influenced by the other solutes that are present. Mazur (Mazur et al, 1969) has coined the term 'solution effects' to include all the changes that occur in the liquid phase as a result of freezing and the effects that they have on any cells that are also present in the system.

It is important to realize that ice formation is normally entirely extracellular. There are several reasons for this. In the first place, when heat is removed by conduction from the external surface of the specimen, the coldest point will always be in the extracellular fluid. Secondly, the extracellular fluid forms one large compartment, whereas the intracellular space consists of very many small compartments: the probability of ice nucleation occurring in any given compartment is directly related to its size, and this makes it inevitable that nucleation will occur in the extracellular fluid before a significant number of cells have frozen internally. Once ice has started to form, it will propagate throughout that compartment until equilibrium is reached. Hence, even if a few cells should freeze internally before extracellular freezing starts, once extracellular ice has formed it will continue to grow in that space, and since cell membranes are impermeable to the main solutes present, water will be withdrawn from the cells by the increased external osmolality. Hence the cells will shrink, and so long as cooling is slow enough to allow water to leave the cells to maintain equilibrium, no further intracellular freezing will occur. Let us look next, therefore, at the effects of raised external osmolality, and then return later to the possibility of intracellular freezing at rapid cooling rates.

Clearly, the most obvious effect of raised external osmolality is that cells shrink. Farrant and Woolgar $(1972 a, b)$ measured the mass of water in erythrocytes exposed to solutions of sodium chloride and sucrose and showed that the cells reached a minimum volume at about $1800-2000 \mathrm{mOsm} / \mathrm{kg}$. Meryman (1968) suggested that when the osmolality is increasedo beyond this value, an actual hydrostatic pressure $\frac{\bar{\sigma}}{\bar{D}}$ difference is produced across the cell membrane, $\frac{\bar{\rho}}{\bar{\sigma}}$ and that this may then damage the cell. However,, $\mathbb{\varrho}$ this seems distinctly unlikely, because intracellularo proteins reach such a high concentration underthese conditions, and their osmotic properties are so ${ }_{-}^{\circ}$ extremely non-ideal, that very small water move- $\vec{\omega}$ ments are sufficient to maintain equal water activity on either side of the cell membrane. Certainly the membranes are damaged however; they becomein leaky to cations, and significant cell lysis is observed ${ }_{+}$ but this effect is not sufficient to explain the damagei observed during freezing. Three observations madeon human erythrocytes by Daw et al (1973) illustrate음 this. First, the amount of haemolysis produced at agiven osmolality without freezing was less than that observed when the same osmolality was produced by freezing. Moreover there was less damage when $\vec{\omega}$ cells were frozen in sucrose instead of sodium $/$ chloride, whereas the same shrinkage and haemolysis was produced by exposure to sycrose without freezing. In addition, freezing was found to render red cell membranes permeable to sucrose, whereas exposure to equivalent osmolalities without freezing $\frac{\circ}{\square}$ did not. Clearly, additional factors were at work $\stackrel{\varrho}{\overrightarrow{2}}$ during freezing.

The obvious differences between the simple hypertonic model system and actual freezing are that freezing and thawing involve changes in temperature as well as concentration, and thato응 during thawing the cells are resuspended in the original osmolality. Lovelock in 1955 showed that erythrocytes suspended in hypertonic salt solutions, $\stackrel{0}{\circ}$ sufficient to produce only minimal haemolysis if the temperature was held constant at $37^{\circ} \mathrm{C}$, were lysed $\mathrm{O}$ when cooled to $0^{\circ} \mathrm{C}$ (see fig 1). This is a thermal $>$ shock' phenomenon, possibly analogous to that which occurs naturally with some species of bacteria N (Meynell, 1958) and spermatozoa (Smith, 1961a) but ${ }^{\circ}$ which occurs with erythrocytes only when they have $\stackrel{N}{\circ}$ been appropriately sensitized. Lovelock (1955) స్ట showed that hypertonic conditions elute lecithin from erythrocyte membranes, and he suggested that 0 the low melting point of this lipid makes lecithin- $\bar{\Phi}$ rich membranes more pliable at low temperatures $\stackrel{\oplus}{+}$ and therefore less liable to fail under the stresses 0 produced by differential thermal contraction. This $\frac{\bar{D}}{\vec{D}}$ phenomenon must also occur during freezing $\stackrel{\odot}{?}$ because the cells are then exposed to rising salt $\stackrel{\AA}{\AA}$ concentrations and falling temperature at the same time.

Lovelock (1953a) also carried out a very elegant 


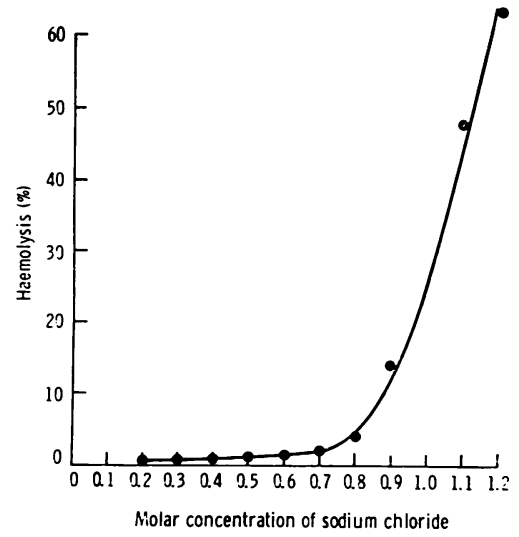

Fig 1 Haemolysis produced by cooling human red blood cells from $37^{\circ} \mathrm{C}$ to $0^{\circ} \mathrm{C}$ at $20^{\circ} \mathrm{C} \mathrm{min}-1$ in concentrations of sodium chloride ranging from $0 \cdot 2$ molar to $\mathbf{J} \cdot 2$ molar.

experiment showing that red cells exposed to hypertonic saline were damaged further when they were returned to isotonic conditions. He showed that when erythrocytes were frozen in $0.15 \mathrm{M}$ sodium chloride they could not be recovered without lysis if they spent more than 30 seconds in the temperature zone between -4 and $-40^{\circ} \mathrm{C}$. He pointed out that $-4^{\circ} \mathrm{C}$ is the freezing point of $0.8 \mathrm{M}$ sodium chloride, and that therefore as the cells are cooled through this zone they are exposed to external sodium chloride concentrations increasing from $0.8 \mathrm{M}$ at $-4^{\circ} \mathrm{C}$ to $5 \cdot 2 \mathrm{M}$ at $-21 \cdot 1^{\circ} \mathrm{C}$. Lovelock then showed that when erythrocytes were suspended in sodium chloride solutions varying from 0.6 to $3.6 \mathrm{M}$, the haemolysis produced when they were resuspended in $0.15 \mathrm{M}$ sodium chloride was the same as that which occurred when suspensions in isotonic saline were frozen to the temperature which results in the same concentration and then thawed again (see fig 2).

Thus, we now look upon the damage occurring during slow cooling, when ice is exclusively extracellular, as being due solely to solution effects and consider that this damage occurs in two stages: in the first stage, latent damage is sustained by the membranes, principally, but not necessarily solely, as a result of the concentrated electrolyte solutions produced by freezing; in the second stage, this damage is manifested by the additional stresses of cooling (thermal shock) and resuspension in isotonic saline as a result of thawing (dilution shock). Farrant and Morris (1973) have recently stressed the importance of thermal shock, arguing that since cooling occurs before redilution, thermal shock is likely to have destroyed the sensitized cells before dilution shock can do so.
This discussion so far has been limited to slow cooling where ice is exclusively extracellular. Since the processes that sensitize the cell membrane to damage on cooling or dilution are chemical in nature, and since all chemical reaction rates are temperature-dependent, it would be anticipated that accelerating the cooling rate would increase cell survival because the cells would then be exposed to the damaging solution effects for shorter times at high temperatures. Direct experiment has confirmed this expectation but has also shown that survival eventually falls off if the cooling rate is increased still further. Mazur (1963) has produced a very convincing explanation for this phenomenon. He pointed out that red cells, which have a high permeability for water, have a high optimum cooling rate, whereas yeast, which is relatively impermeable to water, survives better at low cooling rates: it follows from the permeability data that yeast cells will tend to freeze internally at lower cooling rates than erythrocytes, and he was able to show that significant amounts of supercooled intracellular water start to occur in yeast at $10^{\circ} \mathrm{C} / \mathrm{min}$, and at $3000^{\circ} \mathrm{C} / \mathrm{min}$ in erythrocytes. These happen to be the cooling rates giving maximum survival with each of these cells, and if one postulates that intracellular freezing is damaging, by some mechanism as yet unknown, then the actual effect of cooling rate on cell survival can be explained. There is now direct experimental confirmation, both from light microscopy (Diller et al, 1972) and from electron

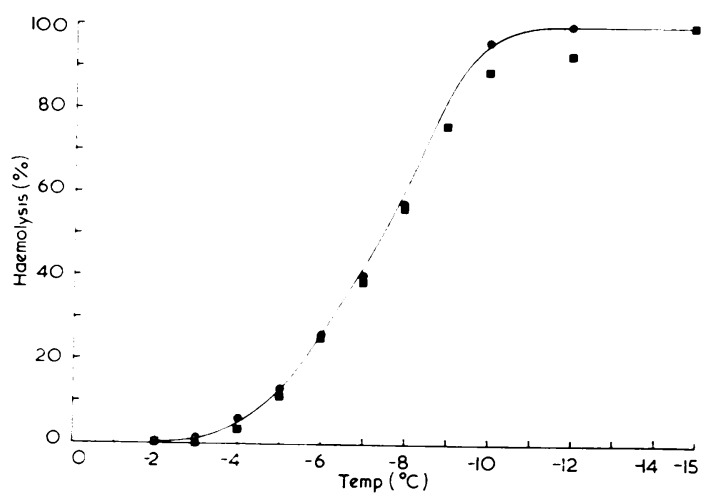

Fig 2 Haemolysis produced by exposing red cells suspended in $0.15 \mathrm{M} \mathrm{NaCl}$ solution to the temperatures indicated and rewarming them (O). The haemolysis produced by exposing red cells to solutions having the indicated freezing points, and then returning them to isotonic saline are also shown ( $)$. The agreement between the data is apparent. (Data from Lovelock (1953a) reproduced by permission of Blackwell Scientific Publications) 


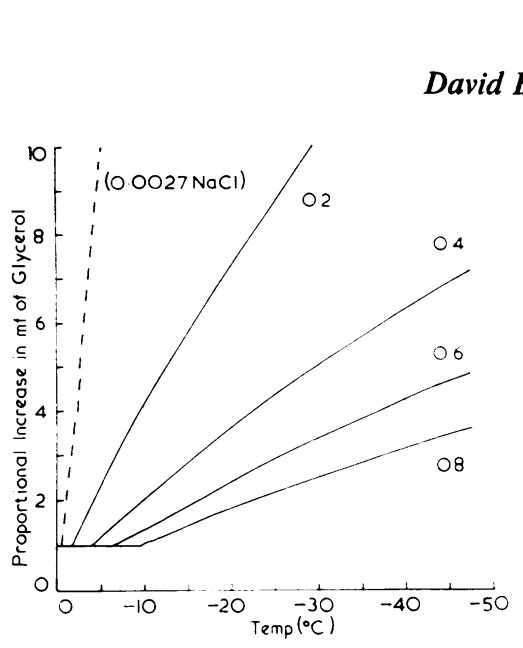

microscopic examination of freeze-substituted material (Walter et al, 1975), that intracellular freezing does occur during rapid cooling and is associated with cell destruction. Figure 3 shows the effect of cooling rate on the survival of four cell types; note particularly that mouse bone marrow cells, which are typical nucleated mammalian cells, show less than $2 \%$ survival at any cooling rate. This is explained by postulating that accelerating the cooling rate causes internal freezing to occur before the rate is fast enough to reduce significantly the damage from solution effects. If this is correct, a useful survival rate would be obtained if some method could be found to reduce solution effects at cooling rates slow enough to avoid intracellular freezing. It is fortunate that the accidental discovery of the cryoprotective action of glycerol did exactly this.

\section{Cryoprotection}

The historic discovery of the cryoprotective effect of glycerol was made in 1948 when Polge et al (1949) found that fowl spermatozoa that had been cooled to $-79^{\circ} \mathrm{C}$ in $1.1 \mathrm{M}$ glycerol recovered with little damage after thawing. Mammalian erythrocytes behaved similarly. Lovelock (1953b) explained the cryoprotective action of glycerol on the basis of colligative action; he demonstrated that the rise in salt concentration when isotonic sodium chloride solution was frozen was much greater than the rise in glycerol concentration when biologically acceptable concentrations of glycerol were frozen (see fig 4). It followed, of course, that when both sodium chloride and glycerol are present, they will both be

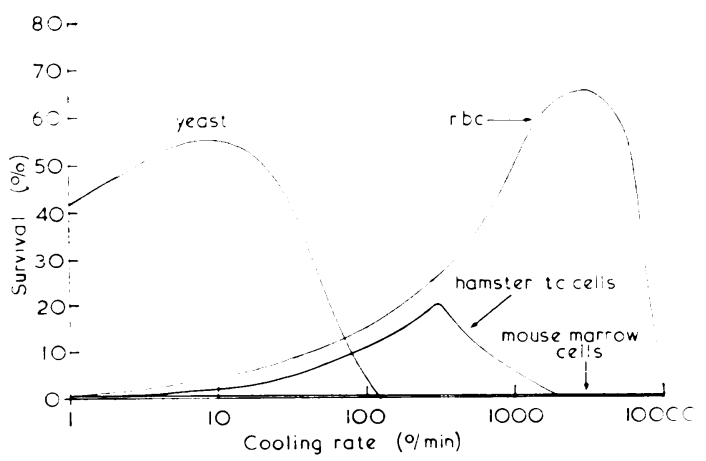

Fig 3 Graph showing the effect of cooling rate on the survival of yeast cells, tissue culture cells (hamster TC cells), human red blood cells, and mouse bone marrow cells. Note the differing optimum cooling rates, and the fact that less than $2 \%$ of the bone marrow cells survive at any cooling rate. (Reproduced by permission of IPC Science and Technology Press Ltd)
Fig 4 Graph showing the rise in concentration of the indicated initial mole fractions of glycerol $(\longrightarrow)$ compared with isotonic sodium chloride $(0.0027 \mathrm{mf}$ $---)$. It is apparent that the increase in mole fraction of $\mathrm{NaCl}$ in a solution that also contains significant amounts of glycerol will be greatly reduced. (Reproduced by permission of Blackwell Scientific Publications)

concentrated to the same proportional extent, sincer it is the removal of solvent water to form ice that is concentrating both solutes. He showed that theo reduction in salt concentration achieved by theo addition of glycerol to a suspension of erythrocytes in physiological saline exactly paralleled the reduc- $\overrightarrow{0}$ tion in haemolysis when the suspension was frozen. 3 Whatever the glycerol concentration, haemolysis started when the sodium chloride concentration? reached a mole fraction of 0.014 , and reached $5 \%$ whenever the mole fraction of sodium chloride:increased to 0.02 , irrespective of temperature or 3 . glycerol concentration (see fig 5).

Nash (1962) studied many other neutral solutes that are cryoprotective for erythrocytes and found $\mathrm{O}$ that they had the common properties of ability to penetrate cells, lack of toxicity, and a high affinity foro water. Clearly, the latter two characteristics are vital; the absence of intrinsic toxicity is a self- $-\sigma$ evident requirement, and the ability to producen concentrated solutions with a low freezing point is important because such compounds will be the most $\sigma$ effective 'salt buffers'. However, the fact that many commonly used cryoprotective agents penetrate cell: membranes actually produces some problems and is certainly not a necessary property for cryoprotection.

Penetrating cryoprotective agents like glycerol and ${ }^{\circ}$ dimethylsulphoxide (DMSO) permeate a good deal more slowly than water and consequently they all produce osmotic transients, the severity and duration $\frac{}{\sigma}$ of which vary with the compound and the cell in question. In general, osmotic disturbances haveo 


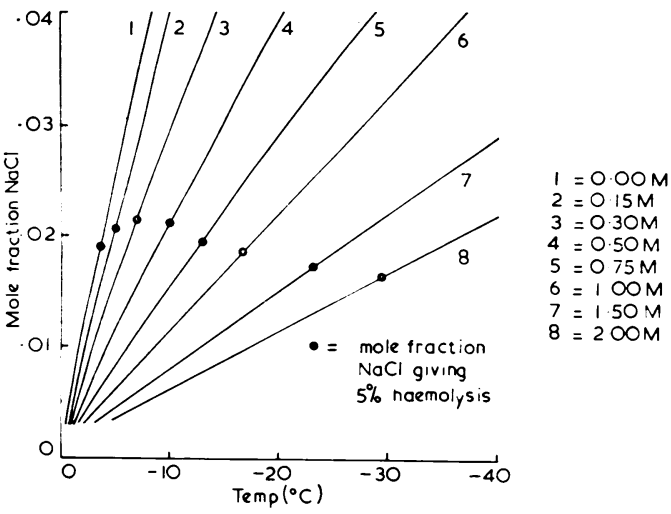

Fig 5 Graph showing the rise in mole fraction of $\mathrm{NaCl}$ in solutions initially containing the indicated molalities of glycerol and isotonic with respect to $\mathrm{NaCl}$. When red blood cells were suspended in these solutions $5 \%$ haemolysis was observed at a different temperature in each case, but the corresponding mole fraction of $\mathrm{NaCl}$ was always 0.016-0.021. (Data from Lovelock (1953b) reproduced by permission of Blackwell Scientific Publications)

more severe effects during thawing and resuspension of the cells in cryoprotectant-free medium (when the solute is leaving the cells) than during initial equilibration and cooling (when it is entering the cells). This is due to the greater sensitivity of cells to swelling than to shrinkage. It is certainly very important to minimize osmotic disturbances during thawing and subsequent manipulations since they can contribute very significantly to the damage suffered by stored cells and tissues (Thorpe et al, 1975). When this is done it is found that many of the most effective cryoprotectants do penetrate cells, and Lovelock actually showed that if erythrocytes are rendered relatively impermeable to glycerol by treatment with $\mathrm{Cu}^{++}$ions, they are less completely protected by glycerol.

In 1955 Bricka and Bessis showed that erythrocytes suspended in high concentrations of dextran or polyvinylpyrrolidone (PVP) would survive freezing at very low temperatures, and it was subsequently shown that PVP would protect bone marrow and tissue culture cells (Mazur et al, 1969). For many years it was supposed that such macromolecular compounds must have a different mechanism of action from glycerol, because the mole fraction of the protective compound was very low. However, the solution properties of macromolecules are well known to be very non-ideal (Jellinek and Fok, 1967), especially in high concentration, and Farrant and Woolgar (1970) have shown that the presence of $15-30 \%$ of PVP depresses the rise in salt concentra- ion of the system PVP-NaCl- $\mathrm{H}_{2} \mathrm{O}$ sufficiently to enable red cells to survive exposure to $-10^{\circ} \mathrm{C}$ for 20 minutes. Even though these compounds do not penetrate into the cells they will, of course, reduce the build-up of salt concentration inside the cells, since intracellular solute concentration will be in equilibrium with external salt concentration, which is reduced. An additional factor has been pointed out by Woolgar (1972), who showed that haemolysis was reduced by the presence of external colloid (PVP) when frozen red cell suspensions were thawed; this was probably due to the balance that the PVP provided for the intracellular colloid once the cell membranes had become leaky to cations. Other more specific actions of certain high molecular weight materials may also play a part in cryoprotection, but it seems likely that the most important action of high molecular weight, non-penetrating cryoprotective agents is the same as that proposed by Lovelock for glycerol.

It will be appreciated that all these cryoprotective agents affect only the part of the graph relating damage to cooling rate which has been ascribed to solution effects. This was very elegantly demonstrated by the study of Leibo et al (1969), who showed for mouse bone marrow cells that increasing the glycerol concentration produced progressively greater surviving fractions at progressively lower cooling rates, but left the 'intracellular freezing' part of the curve completely unaffected (see fig 6).

\section{Cell Preservation}

Long before much of the fundamental information reviewed above was available, experimental investi-

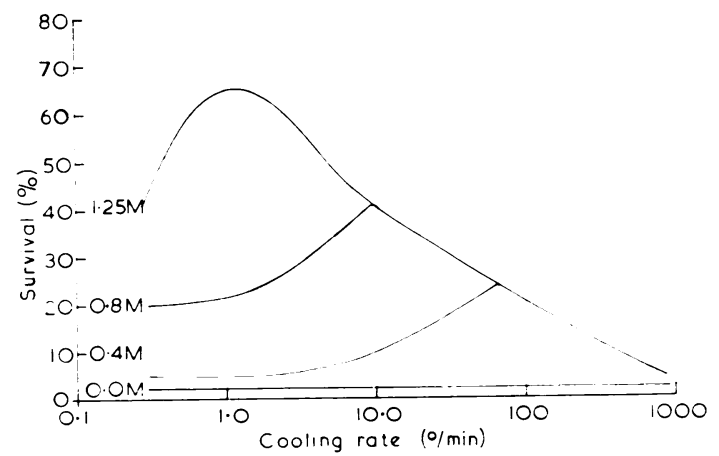

Fig 6 Graph showing the effect of cooling rate on the survival of mouse haemopoietic cells cooled in the presence of various concentrations of glycerol. Note that increasing the glycerol concentration moved the optimal cooling rate downwards and increased maximum survival. (Data from Leibo et al (1969) reproduced by permission of IPC Science and Technology Press) 
gation had shown that many cells could be preserved by 'slow' $\left(\sim 1^{\circ} \mathrm{C} \mathrm{min}{ }^{-1}\right)$ cooling in the presence of moderate (1-2 molar) concentrations of glycerol or DMSO, and this came to be regarded as the 'standard technique'. The accumulation of information on the mode of action of cryoprotectants and the effect of cooling rate has shown that this is far too simple a view; each cell should be considered separately since variation of the cooling rate, the cryoprotective additive, and the technique of post-thaw handling will produce different, sometimes very different, optimum conditions for the storage of each cell. Moreover, it should not be assumed that the maintenance of a single cooling rate throughout the process is optimal; in the original work on spermatozoa, Polge and Lovelock (1952) obtained their best results by cooling at $1^{\circ} \mathrm{C} \min ^{-1}$ to $-15^{\circ} \mathrm{C}$ and then at $5^{\circ} \mathrm{C} \mathrm{min}{ }^{-1}$, and the same technique has been used for bone marrow (Pegg, 1964a) and other cells (Smith, 1961b). Luyet and Keane (1955) developed a method known as two-step cooling in which cells, suspended in a medium containing a suitable cryoprotective agent, are cooled rapidly to a critical subzero temperature, are held at that temperature for a sufficient length of time, and are then cooled rapidly to the storage temperature, usually $-196^{\circ} \mathrm{C}$. Studies recently carried out by Walter et al (1975) have shown that during the holding time, when the cells are exposed at a low temperature to a high external osmolality, they shrink, and that when they are then cooled rapidly, they do not freeze internally. Thus, the mechanism of cryoprotection is precisely the same as that in controlled-rate cooling, but because the cells are dehydrated at a lower temperature, where chemical reaction rates are slower, it seems reasonable to predict that overall survival may be improved over the controlled-rate technique where the cells spend longer at higher temperatures during freezing. So far the two-step method has been shown to be applicable to bull spermatozoa (Luyet and Keane, 1955), human lymphocytes, and hamster fibroblastic tissue culture cells (Farrant et al, 1974); $-25^{\circ} \mathrm{C}$ seems to be a suitable holding temperature and 10 minutes a sufficient time. The maximum reported survival rates have exceeded those obtained by controlled-rate methods, but so far the method has proved successful only with samples of $0.5 \mathrm{ml}$ or smaller.

It will be realized therefore that there are a variety of techniques available for cell preservation, and in the present state of knowledge there is no certain way of predicting the optimum method for an as yet untested cell. In the rest of this paper I propose to review the methods that have been worked out for cells and tissues that are of particular interest to pathologists.

\section{Applications in Haematology}

Of all the medical specialities, haematology has $\underset{\vec{D}}{\stackrel{\vec{D}}{\overrightarrow{0}}}$ provided the greatest number and some of the most $\frac{7}{0}$ important applications of cryobiology. The clinical $\frac{}{0}$ transfusion of red blood cells and platelets renders $\overline{\bar{\omega}}$ some form of storage mandatory; currently, there $\widehat{\Phi}$ is a resurgence of interest in bone marrow transplantation and granulocyte transfusion, so preserva- ${ }^{\infty}$ tion of these cells is also relevant; lymphocytes are $\vec{\circ}$ stored for laboratory reference purposes in tissue $\overrightarrow{\vec{H}}$ typing and cytogenetic analysis. We will examine the $\stackrel{\omega}{\omega}$ requirements for successful preservation of each of 옹 these cell types in turn.

PRESERVATION OF ERYTHROCYTES

Figure 3 shows the relationsip between cooling rate and survival for unprotected human erythrocytes. The high water permeability of these cells makes them very resistant to intracellular freezing, and $D$ consequently it is possible to obtain usable recovery rates in the absence of any cryoprotectant. The $\vec{\varphi}$ addition of low concentrations of glycerol, for example, or of non-penetrating agents that dehydrate the cells slightly before freezing makes it possible to obtain virtually $100 \%$ survival with rapid cooling. The development of practical preservation methods based on these observations is a simple matter if small volumes are sufficient and sterility is not $\propto$ required, as is the case, for example, with serological $\overrightarrow{\vec{o}}$ testing. Meryman and Kafig (1955) described one 3 such technique; blood, to which sufficient glucose had been added to yield a final concentration of $7 \%$, was sprayed from a syringe fitted with a fine needle onto the surface of liquid nitrogen. The droplets $:$ froze separately and then sank to the bottom of the 3 . liquid nitrogen where they were stored; thawing was 8 carried out by sprinkling into warm saline. Huntsman et al (1960) found 13\% sucrose to give higher 0 survival rates; they recommended the dilution of EDTA-anticoagulated blood with one half its volume of $40 \% \mathrm{w} / \mathrm{v}$ sucrose solution immediately before dispensing drop by drop into a container of $\sigma$ liquid nitrogen. Alternatively, the cell suspension $N$ may be held as a film on a piece of stainless steel $\underset{\mathrm{E}}{ }$ gauze, which is then dipped into liquid nitrogen $O$ (Bronson and McGinniss, 1962), a technique that avoids the possibility of frozen droplets from different blood samples getting mixed.

Provided that a well insulated Dewar vessel is 0 used for storage, the samples may be stored in the gas phase above the liquid nitrogen where the temperature should be below $-160^{\circ} \mathrm{C}$.

Attempts to adapt this sort of technique to the sterile storage of pint volumes of blood for transfusion met with great difficulties. Special flat or 
corrugated metal cannisters were developed and techniques were devised for accelerating heat transfer from them into liquid nitrogen during immersion cooling (Strumia et al, 1960) but it proved impossible to devise a method that would give satisfactory haemolysis rates and post-transfusion survival figures without the use of relatively high concentrations of cryoprotectants. Once this restriction had been accepted, and with it the need to remove the cryoprotectant after thawing and before transfusion, then the requirement for very rapid cooling was removed, because increasing the cryoprotectant concentration made much slower cooling perfectly acceptable. Glycerol has been the most widely used cryoprotectant, and since erythrocytes will withstand very high concentrations of glycerol, their storage in the presence of 3-4 M glycerol presents little difficulty, and the cooling rate does not need to be controlled. With such high concentrations of glycerol the storage temperature may even be as high as $-45^{\circ} \mathrm{C}$ with reasonably acceptable levels of haemolysis, although $-80^{\circ} \mathrm{C}$ is really preferred. The serious technical difficulty with this technique is the removal of glycerol after thawing since this must be performed slowly if serious osmotic imbalance, with consequent haemolysis, is to be avoided. Slow stepwise dilution or dialysis against glycerol-free saline are effective but are time-consuming, and sterility is difficult to maintain. However, if the glycerol technique is being used for small volumes of blood intended for serological testing, then dialysis is both simple and convenient; one hour's dialysis in a $20 \mathrm{~cm}$ piece of Visking tubing immersed in a $200 \mathrm{ml}$ beaker of physiological saline is satisfactory for $5 \mathrm{ml}$ samples (Weiner, 1961).

The first really practical method of removing glycerol from pint volumes of blood for transfusion involved the use of the Cohn ADL fractionator for continuous washing of the cell suspension. The thawed glycerolized blood was run into the sterilized bowl revolving at $4000 \mathrm{rev} / \mathrm{min}$, and followed by 4 litres of solution of progressively decreasing glycerol content, starting at $1.1 \mathrm{M}$ and falling to zero over about 90 minutes. The residual glycerol content was typically $0.05-0.1 \quad M$ and the post-transfusion recovery was $85-90 \%$ (Pyle, 1964). There were considerable difficulties in the washing and sterilizing of the bowls but this problem was overcome by the introduction of disposable plastic bowls. Other manufacturers have now entered the market with simple continuous-flow centrifuges using disposable bowls, and the problem is now one of cost-typically $£ 18$ per wash at the time of writing.

An alternative and somewhat simpler method that avoids the need to centrifuge was introduced by
Huggins (1963). He observed that when erythrocytes are suspended in slightly acid media containing less than $0.02 \mathrm{M}$ salts but rendered isotonic with sugars, the cells aggregate to form large clumps that sediment rapidly. When these cells are returned to isotonic saline or plasma they disperse and can be recovered with very little haemolysis. Huggins used this phenomenon to remove dimethylsulphoxide or glycerol from thawed red cell suspensions: first the agglomerating sugar solution was run into the cell suspension, then the suspension was stirred and time was allowed for the glycerol to diffuse out, the stirring was stopped, and the cells settled rapidly under gravity. The supernatant was then removed and three washes of approximately 1 litre each were carried out in a similar way. Finally, the cells were resuspended in saline. By using special blood bags this process can be completed in 20 minutes and one technician can handle 5 pints simultaneously. The disadvantages of this method are the large volume of wash solution required, the rather high cost of the special blood bags (although they are much cheaper than disposable centrifuge bowls), and the fact that recovery tends in most hands to be somewhat less efficient than with centrifugal washing methods.

Both of the methods described so far have been extensively used in the USA but in Europe, and increasingly in North America also, blood banks have preferred to use a lower concentration of glycerol $(1.9 \mathrm{M})$ although this requires more rapid cooling and storage in liquid nitrogen. Several variations of the technique are in use: the method described by Rowe (1974) is as follows: packed red cells are mixed with an equal volume of $3.8 \mathrm{M}$ glycerol and frozen rapidly $\left(90^{\circ} \mathrm{C} \mathrm{min}-1\right)$ in special flattened plastic bags. They are stored in liquid nitrogen refrigerators at $-196^{\circ} \mathrm{C}$. When required for transfusion, the bag is thawed by agitation in a $45^{\circ} \mathrm{C}$ water bath and washed with $300-500$ $\mathrm{ml}$ of $15 \%$ mannitol or $3.5 \%$ sodium chloride solution followed by 2 litres of physiological saline either in three batches using a four-tail bag and a conventional centrifuge or an automatic serial washing centrifuge, or continuously using a continuous-flow, disposable-bowl centrifuge. This method gives an in vitro cell recovery of $\sim 97 \%$ and a 24-hour in vivo survival of $95 \pm 2 \%$.

Thus there is a range of techniques available for the long-term preservation of erythrocytes for laboratory and clinical use. When liquid nitrogen storage temperatures are used, there is no perceptible deterioration during storage, and ATP, 2-3 DPG, and intracellular $\mathrm{K}^{+}$levels are all fully maintained.

PRESERVATION OF PLATELETS

Platelets are considerably more difficult to preserve 
than erythrocytes. Baldini et al (1960) obtained only $20 \%$ survival of platelets after storage for 24 hours at $-75^{\circ} \mathrm{C}$ in the presence of $1.2 \mathrm{M}$ glycerol. Higher concentrations of glycerol produced lower survival figures in their hands, but Cohen and Gardner (1966) found that glycerol toxicity could be greatly reduced by using extremely gentle methods of deglycerolization following thawing; the maximum tolerated concentration then rose to $1.7 \mathrm{M}$, but the proportional survival was only $23 \%$. Since platelets seem to be particularly susceptible to osmotic shock, it is not surprising that DMSO, which diffuses much more rapidly than glycerol, should have given somewhat better results. Iossifides et al (1963) reported an estimated $30 \%$ recovery after storage at $-196^{\circ} \mathrm{C}$ with $2 \cdot 1 \mathrm{M}$ DMSO in plasma for five weeks. Djerassi and Roy (1963) found that a lower concentration of DMSO $(0.7 \mathrm{M})$ combined with $0.28 \mathrm{M}$ dextrose yielded $70 \%$ platelet recovery immediately after infusion into $x$-irradiated animals, and $30 \%$ survival 24 hours later. Fresh platelets, in their hands, showed a $65 \%$ survival at 24 hours, so the preserved platelets were about one half as effective as the fresh material. The value of the added glucose is doubtful, however; Murphy et al (1974) found it to be without significant effect, but they confirmed the superiority of $0.7 \mathrm{M}$ DMSO over previous experience with glycerol. Valeri's laboratory has now developed the DMSO technique to the point where it can be used clinically (Handin and Valeri, 1972; Valeri et al, 1974). They have stressed the desirability of removing DMSO before transfusion and, by adding the DMSO slowly and removing it by a stepwise dilution technique, they have obtained an in vivo survival figure of $47 \%$ compared with $65 \%$ for fresh platelets. The lifespan of the platelets was normal and there were no adverse transfusion reactions. In this study the cooling rate was controlled at $1^{\circ} \mathrm{C} \min ^{-1}$ and the storage temperature was $-150^{\circ} \mathrm{C}$, but in a later report equa!ly good results were obtained when cooling and storage were achieved simply by placing the 30 $\mathrm{ml}$ bags in $\mathrm{a}-80^{\circ} \mathrm{C}$ refrigerator; the cooling rate was then approximately $2-3^{\circ} \mathrm{C} \mathrm{min}-1$. A full clinical assessment of this technique is now urgently required.

PRESERVATION OF BONE MARROW

Barnes and Loutit (1955) were the first workers to show that haemopoietic cells from the spleens of infant mice would survive storage at $-79^{\circ} \mathrm{C}$ if they were cooled at approximately $1^{\circ} \mathrm{C} \mathrm{min}-1$ to $-15^{\circ} \mathrm{C}$ and then more rapidly, and if the suspending medium contained $2.0 \mathrm{M}$ glycerol. These results have been confirmed by many workers using actual bone marrow cells of many species, viability being assessed by the ability to recover lethally irradiated animals.
DMSO has also been shown to be effective but the relative efficiency of the two compounds is in some $\frac{\text { o }}{\text {. }}$ doubt: Ashwood-Smith (1961) found DMSO to be $\vec{F}$ superior, whereas Kurnick (1968) found that glycerol? was more effective and van Putten (1965) obtained듬 identical results with each compound. For clinical $\frac{O}{\infty}$. use the balance probably tips in favour of glycerol $\vec{\sigma}$ for two additional reasons: glycerol is a physiological 응 compound that has been widely used for red cellos preservation without any evidence of harmful side $\vec{\circ}$ effects, whereas there are some doubts about $\mathrm{DMSO}_{-}^{-}$ (Smith et al, 1967), and this compound has the $\mathrm{\sigma}^{-}$ undesirable effect of causing the recipients of significant quantities to acquire a most unpleasant sulphide ${ }_{i}$ odour. Other cryoprotectants have been studied inco experimental animals, and PVP has been shown to be effective in rats (Persidsky et al, 1965). van Putten (1965) made the interesting observation thato a combination of $1.4 \mathrm{M}$ glycerol and $10 \% \mathrm{PVP}$ is more effective than either compound separately in $>$ the preservation of monkey bone marrow cells, and으․ this is probably the technique of choice for clinical use. In spite of early worries about the toxicity of PVP, there seems to be no reason why a low molecu-s lar weight fraction such as K-15 should not be usedo clinically. Unfortunately the relatively precises spleen-colony assay for stem cell survival cannot beo used with human marrow, and since direct testing in lethally irradiated individuals is clearly inapplicable, $\stackrel{\mathbb{Q}}{\circ}$ one is forced to rely on in vitro techniques for $\overrightarrow{\overrightarrow{0}}$ quantitative measurements of survival rates for 3 preserved human bone marrow cells. These are not entirely satisfactory (Pegg, 1964b) although improvements in the semisolid culture method of Bradleys and Metcalf (1966) should soon provide more reliable data. In the meantime one is forced to rely3. on the evidence from studies in experimentals animals and the results of limited clinical studies (Pegg, 1964a). On this evidence the followingo procedure is suggested:

1 Dilute the bone marrow suspension with and equal volume of balanced salt solution contain $\overline{\bar{N}}$ ing 3 M glycerol, possibly with $20 \% \mathrm{~K} 15$ PVP, and allow 30 minutes at $4^{\circ} \mathrm{C}$ for equilibration. $N$

$2 \mathrm{Cool}$ the suspensions at $1-2^{\circ} \mathrm{C} \mathrm{min}^{-1}$ to $-100^{\circ} \mathrm{C}$ and store at $-196^{\circ} \mathrm{C}$.

3 Thaw rapidly by agitation in a $40^{\circ} \mathrm{C}$ water bath

4 Administer the suspension intravenously with $\frac{0}{\Phi}$ out prior dilution or manipulation.

Attempts have been made to remove the cryoprotec- -0 tant before administration, but this results ins unacceptably high cell losses (Pegg, 1964c) and is not recommended with presently available techniques

PRESERVATION OF GRANULOCYTES It has been known for many years that lethallo 
irradiated animals may be recovered by the infusion of large quantities of peripheral blood leucocytes (Cavins et al, 1964) although it is uncertain whether this is due to the presence of adequate numbers of stem cells in the peripheral blood, or to temporary support for a sufficient time to permit natural recovery of the irradiated marrow. The clinical application of these observations was difficult until the development of cell separators made it relatively easy to collect the very large numbers of cells required, and there is now a resurgence of interest in the possibility of using granulocyte transfusion in leucopenic patients with severe bacterial or fungal infection (Lowenthal and his colleagues, 1975; Vallejos and his colleagues, 1975). Clearly, such a clinical programme would be simplified if it were possible to store granulocytes for long periods of time. Unfortunately, however, granulocytes are extremely susceptible to freezing injury, and attempts to preserve them in the presence of DMSO by slow cooling to $-196^{\circ} \mathrm{C}$ have yielded very low survival rates (Cavins et al, 1965; Cavins et al, 1968). Knight et al (1975) have shown that human granulocytes are severely damaged by rapid cooling to $-15^{\circ} \mathrm{C}$ even if they are supercooled, and that this thermal shock can be prevented by cooling at $0.3^{\circ} \mathrm{C} \mathrm{min}-1$. However, as soon as freezing occurs and the suspension cools again after the evolution of latent heat, the majority of the cells are lost. The mechanism of this damage is not yet known but may be due to the sensitivity of lysosomes to high concentrations of electrolytes (Lee and Allen, 1972).

\section{PRESERVATION OF LYMPHOCYTES}

Lymphocytes resemble bone marrow cells in their requirements for satisfactory preservation, and similar high recovery rates can be obtained with the optimum techniques. Both glycerol and DMSO have been used as cryoprotectants, and it is generally agreed that DMSO is more effective. AshwoodSmith (1964) used 2.1 M DMSO and preserved mouse lymphocytes by cooling at $4{ }^{\circ} \mathrm{C} \mathrm{min}^{-1}$ followed by storage at $-196^{\circ} \mathrm{C}$. Pegg (1965) used somewhat slower cooling to preserve human lymphocytes in $1.4 \mathrm{M}$ DMSO. The interaction between DMSO concentration and cooling rate was studied by Farrant et al (1972), who found that the maximum recovery of CON-A responsive human lymphocytes was obtained at $0.3^{\circ} \mathrm{C} / \mathrm{min}$ in $1.4 \mathrm{M}$ DMSO and at $1{ }^{\circ} \mathrm{C} \mathrm{min}-1$ in $0.7 \mathrm{M}$ DMSO. Thorpe et al (1975) have studied the influence of post-thaw manipulations on the recovery of frozen mouse lymphocytes: they found that dilution of the suspension to remove DMSO should be carried out at $25^{\circ} \mathrm{C}$ rather than at $0^{\circ} \mathrm{C}$, and that the presence of $10 \%$ serum, and the use of low $g$ forces for centrifugation, were beneficial.
Thus, a convenient technique would be to mix the lymphocyte suspension with an equal volume of $1.4 \mathrm{M}$ DMSO in BSS containing $10 \%$ serum, cool at $0.3^{\circ} \mathrm{C} \mathrm{min}^{-1}$, and store at $-196^{\circ} \mathrm{C}$. When required, the suspensions should be thawed rapidly in a $40^{\circ} \mathrm{C}$ water bath, then placed in a $25^{\circ} \mathrm{C}$ bath and diluted 10 -fold using $10 \%$ serum in BSS taking about 2 minutes to complete the dilution, and finally centrifuged at $60 \mathrm{~g}$ to deposit the cells.

The two-step cooling procedure can also be used to preserve small volumes of lymphocyte suspension (Farrant et al, 1974); $0.2 \mathrm{ml}$ aliquots in $0.7 \mathrm{M}$ DMSO can be cooled rapidly in small glass vials by placing them in a bath at $-25^{\circ} \mathrm{C}$, and after 10 minutes the vials are transferred to liquid nitrogen at $-196^{\circ} \mathrm{C}$. The cells are thawed and diluted as before, and $100 \%$ recovery has been reported. This technique is remarkably effective but may turn out to be somewhat limited in its practical application since preliminary results indicate lower recovery rates when the sample volume is increased to $1 \mathrm{ml}$.

\section{Applications in Microbiology}

Viruses and bacteria differ from the mammalian cells that we have considered so far in that many of them, although not all, are remarkably resistant to freezing injury so that recovery can be obtained even without the help of cryoprotectants. Indeed, many species can be fi eeze-dried. Space does not permit of a comprehensive review of freezing and drying of microorganisms here; for this, reference should be made to Fry (1966) and to Grieff and Rightsel (1966), but a brief survey, with emphasis on basic principles, will be given here.

\section{PRESERVATION OF BACTERIA}

Some bacteria, and most spores, will survive practically any freezing and thawing procedure; spores, of course, contain relatively little freezable water so their resistance is hardly surprising. Most micrococci, streptococci, and staphylococci are highly resistant, while the bacillus, lactobacillus, and pseudomonas species are rather more easily damaged. In general, even if the organisms will withstand freezing and thawing per se, the survival rate falls off with storage time, unless the temperature is below $-60^{\circ} \mathrm{C}$. This characteristic is highly dependent on the composition of the suspending medium (Woodburn and Strong, 1960), sugars in particular often being protective. It seems most likely that in bacteria, as in mammalian cells, death is caused by the high salt concentrations produced both internally and externally by freezing, and that sugars act colligatively to reduce electrolyte concentrations. When the temperature is much lower, for example 
$-196^{\circ} \mathrm{C}$, progressive loss during storage is not generally observed.

Some bacteria exhibit thermal shock, that is, they can be destroyed by cooling rapidly even without freezing; this is true of log-phase $E$. coli (Meynell, 1958) for example. Whether intracellular freezing is often a significant factor in freezing damage to bacteria is disputed, but Mazur has produced convincing evidence that it is in the case of rapidly cooled Pasteurella tularensis (Mazur et al, 1957), and it seems likely to be of general importance. Both thermal shock and intracellular freezing can, however, be avoided by slow $\left(\sim 1^{\circ} \mathrm{C} \mathrm{min}-1\right)$ cooling. The protective effect of sugars has already been referred to: $10 \%$ glucose or sucrose may be used, but $1.3 \mathrm{M}$ glycerol is even more effective (Postgate and Hunter, 1961): storage should be at $-80^{\circ} \mathrm{C}$ or $-196^{\circ} \mathrm{C}$ for maximum stability, although the more resistant organisms will survive well at much higher temperatures, even at $-20^{\circ}$ or $-30^{\circ} \mathrm{C}$.

It has been mentioned that many bacterial cells will withstand freeze-drying. In this process water is sublimed at a low temperature under reduced pressure. During the freezing phase that precedes drying, the cells are subjected to the same influences of rising solute concentration and temperature change that have been discussed at length already; steps should be taken to avoid thermal shock and intracellular freezing by cooling slowly, and electrolyte damage may be minimized by using cryoprotectants. Cryoprotective compounds have the additional property of holding a certain amount of water in the specimen at the end of drying, which is important because it has been shown that optimum storage is obtained when the residual moisture level is around $1 \%$ (Scott, 1960). The temperature at which drying is carried out is also of great importance, and if this is allowed to rise above $-30^{\circ} \mathrm{C}$ the recovery rate falls dramatically with many species (Greaves, 1956). Presumably this effect is due to exposure of the cells to strong electrolyte solutions for long periods of time, and it is very disturbing to note that many laboratory freeze-driers in common use do not permit any control of the drying temperature. It is also important to include in the preservation medium some inert material that will give body to the freeze-dried product to facilitate handling and resuspension; one suitable compound is dextran, which has the additional advantage of being cryoprotective. A convenient medium for freeze-drying bacteria is $7.5 \%$ sucrose, to provide cryoprotection and maintain a satisfactory residual moisture, $8 \%$ dextran to produce added bulk, and $2 \%$ sodium glutamate which mops up carbonyl groups in the medium and improves stability during storage (Muggleton, 1960). After cooling slowly $\left(\ngtr 1^{\circ} \mathrm{C} /\right.$ min) drying is carried out at $-30^{\circ} \mathrm{C}$ or below to a residual moisture content of about $1 \%$, and the samples are then sealed in the absence of oxygen and $\overrightarrow{\vec{F}}$ stored at room temperature.

\section{PRESERVATION OF VIRUSES}

Viruses vary in their sensitivity to freezing, but many are highly resistant. For example, members of the pox virus, adenovirus, and papovavirus groups are ${ }^{\infty}$ commonly and very successfully stored at $-20^{\circ} \mathrm{C}$. $\vec{\circ}$ However, this is probably an unwise choice of $\overrightarrow{\vec{\omega}}$ temperature, because a significant liquid phase with $\mathscr{\omega}$ a very high solute concentration will exist in most $\overrightarrow{0}$ media, and in fact herpes simplex virus has been $\mathrm{N}$ shown to survive better at $+4^{\circ} \mathrm{C}$ than at $-20^{\circ} \mathrm{C}$; temperatures below $-60^{\circ} \mathrm{C}$ are much more effective. is Similarly, it has been found that members of the $\triangle$ myxovirus and arbovirus groups can be stored at 을 $-60^{\circ} \mathrm{C}$, particularly if additives such as $50 \%$ sucrose or $35 \%$ sorbitol are included. If solid carbon $D$ dioxide refrigerators are used it is important to exclude $\mathrm{CO}_{2}$ from the ampoules. In the case of $\vec{\varphi}$ strongly cell-associated viruses, such as herpes zoster, the virus can be preserved by storing infected cells in medium containing dimethyl sulphoxide. A concise review of virus freezing, which gives many references to techniques for individual species, has been provided by Melnick (1965). Lyophilization can also be used with many but not all viruses, $20 \% \cong$ serum or skimmed milk usually being included in $\overrightarrow{\overrightarrow{0}}$ the suspending medium. Further details of methods $\exists$ for individual species can be obtained from the review by Grieff and Rightsel (1966).

PRESERVATION OF CELLS AND TISSUES FOR VIRUS ISOLATION

Techniques similar to those used to preserve lymphocytes or bone marrow cells have been found to be effective for many tissue culture cell lines, for instance 응 HeLa and $\mathrm{L}$ cells have been stored for five years by cooling at approximately $1{ }^{\circ} \mathrm{C} \mathrm{min} \mathrm{min}^{-1}$ in serum with $0.65 \mathrm{M}$ glycerol (for $\mathrm{L}$ cells) or $2.75 \%$ glycerol (for $\mathrm{N}$ HeLa cells) and holding at $-79^{\circ} \mathrm{C}$ (Scherer, 1960). ه Porterfield and Ashwood-Smith (1962) found 1.4 M N DMSO to be superior to $1.4 \mathrm{M}$ glycerol for chick fibroblasts and human embryo lung cells. These $\sigma$ findings were confirmed by Dougherty (1962), who found $1^{\circ} \mathrm{C} \mathrm{min}^{-1}$ to be the optimum cooling rate $\frac{\leftarrow}{\varnothing}$ and also demonstrated the value of including serum in the medium. Thawing was carried out rapidly by 0 immersion in a $37^{\circ} \mathrm{C}$ water bath, and the cryo- $\bar{P}$ protectant was removed by dilution with growth $\stackrel{\mathbb{D}}{\mathbb{D}}$ medium over a period of about 5 minutes. This method is of wide but not universal applicability. $\frac{\Omega}{\sigma}$ Chinese hamster lung fibroblasts gave very low survival rates by this method, but survival rose to 
$60 \%$ when they were cooled in $1.25 \mathrm{M}$ glycerol at $100^{\circ} \mathrm{C} \min ^{-1}$ (Mazur et al, 1970), and rapid thawing was vital. Good survival at $10^{\circ} \mathrm{C} \mathrm{min}-1$ was obtained when $15 \% \mathrm{w} / \mathrm{v}$ PVP (MW 40000 ) was used as the cryoprotectant. This study underlines the importance of determining the optimum cooling rate and studying more than one cryoprotectant when faced with a new cell line to store. More recently, it has been shown that hamster lung fibroblasts suspended in 0.65 M DMSO can be cooled rapidly to $-26^{\circ} \mathrm{C}$, held at that temperature for 10 minutes, and then cooled rapidly to $-196^{\circ} \mathrm{C}$. After rapid thawing $75 \%$ survival was obtained (Farrant et al, 1974). Twostep cooling will probably be applicable to other cell lines also.

Organ cultures are sometimes used for viral growth and the investigation of antiviral drugs, but these tissues will not survive storage by the conventional ' $1{ }^{\circ} \mathrm{C} \mathrm{min}^{-1}+1$ to $2 \mathrm{M} \mathrm{DMSO'} \mathrm{method.}$ Morris and his colleagues (1973) studied the interaction of DMSO concentration and cooling rate with embryonic human trachea and obtained excellent recovery, as tested both by ciliary activity and viral growth potential, when the tracheal rings were cooled at $0.3^{\circ} \mathrm{C} \mathrm{min}-1$ in Eagles medium containing $2 \%$ serum and $3.3 \mathrm{M}$ DMSO. It is probable that other tissues will yield satisfactory preservation methods if similar systemic studies are carried out.

PRESERVATION OF PROTOZOAL PARASITES Malarial parasites (Collins and Jeffery, 1963), trypanosomes (Polge and Soltys, 1957), Leishmania (Mieth, 1966), and Trichomonas (McEntegart, 1954) have all been successfully preserved by freezing with various cryoprotectants. In many cases, however, the cooling rate has not been controlled, nor the effect of different cryoprotectants studied. Callow and Farrant (1973) subjected Leishmania tropica to such an investigation and found DMSO to be superior to glycerol, sucrose, and PVP, and showed that cooling at $1.9^{\circ} \mathrm{C} \mathrm{min}-1$ in $1.5 \mathrm{M}$ DMSO gave maximal survival.

\section{Applications in Experimental Pathology}

I would like to conclude this review with a brief survey of cryopreservation techniques that have been developed for a variety of cells and tissues that might be of interest to experimental pathologists, and finally to mention some quite recent work on the preservation of more complex tissues than those we have dealt with so far.

\section{PRESERVATION OF TUMOUR CELLS}

Some experimental tumours can be stored at $-79^{\circ} \mathrm{C}$ or $-196^{\circ} \mathrm{C}$ and retain their transplantability without the use of any cryoprotectant (Ising, 1960) although it is likely that, in some cases at least, this is due to preservation of tumour viruses rather than intact cells (Gye et al, 1949). The addition of glycerol (Hauschka et al, 1959) or DMSO (Greenberg, 1966) has generally yielded more consistent results, but precise information on optimum conditions and quantitative estimations of survival are available for very few malignant cells. Farrant et al (1973) have studied leucocytes from the peripheral blood of patients suffering from acute myeloid leukaemia or chronic lymphatic leukaemia; the cells were cooled at various rates in medium containing $5 \% \mathrm{DMSO}$ and recovery was assessed by thymidine incorporation. They found populations of leukaemic cells that survived at rates both faster and slower than that giving maximal survival of normal lymphocytes, and each population could be recovered after refreezing at its own optimum rate. This interesting study emphasized once more the importance of investigating the interdependence of the cryoprotectant, its concentration, and the cooling rate for each cell type, and introduced the possibility of using cryobiological techniques to separate subpopulations of cells. More experimental work using qualitative assays of cell recovery is required in this field.

\section{PRESERVATION OF EMBRYOS}

A recent innovation of considerable potential significance is the development of a technique for the preservation of early mammalian embryos. Whittingham et al (1972) described experiments in which the effects of suspending medium, cooling rate, final temperature, and warming rate were studied on mouse embryos up to the blastocyst stage. It was found that maximum recovery was obtained when the embryos were cooled at $0.3^{\circ} \mathrm{C} \mathrm{min}^{-1}$ in $1 \mathrm{M}$ DMSO and rewarmed at $4^{\circ} \mathrm{C} \mathrm{min}^{-1}$. Survival reached $70 \%$ with two cell embryos and $20 \%$ with early blastocysts. When they were transferred to foster mothers $65 \%$ of the embryos gave rise to a pregnancy and $40 \%$ of these produced normal fullterm fetuses. The insensitivity to very slow cooling combined with a high sensitivity to rapid thawing is quite remarkable, and so far is unexplained. It is however beyond doubt since the same finding was repeated independently in a similar study carried out at the same time by Wilmut (1972). Wilmut and Rowson (personal communication) have subsequently obtained successful preservation of cow embryos using $2 \mathrm{M}$ DMSO and a cooling rate of $0.2^{\circ} \mathrm{C} \min ^{-1}$.

PRESERVATION OF SIMPLE TISSUES

Billingham and Medawar (1952) showed that rabbit. 
skin could be preserved if it was first soaked in $1.6 \mathrm{M}$ glycerol for 1 hour and then cooled slowly to $-150^{\circ} \mathrm{C}$. Thawing was carried out rapidly by plunging the frozen skin into Ringer's solution at $37^{\circ} \mathrm{C}$, and viability was proved by grafting. Lehr et al (1964) found that DMSO could be used with human skin, and that a range of cooling rates from 0.4 to $8.0^{\circ} \mathrm{C} \mathrm{min}^{-1}$ were equally effective whereas thawing had to exceed $50^{\circ} \mathrm{C} \mathrm{min}{ }^{-1}$ for maximum survival. Cornea is structurally somewhat similar to skin and can be preserved by similar methods; using $1.8 \mathrm{M}$ DMSO and slow cooling it was important to add the DMSO at $4{ }^{\circ} \mathrm{C}$ rather than at room temperature in order to minimize toxic effects (O'Neill et al, 1967).

In the 1950s Smith and Parkes showed that a wide variety of embryonic tissues could be preserved by 'slow' cooling in media containing serum and $2 \mathrm{M}$ glycerol: this included ovarian granulosa (Smith, 1952), anterior pituitary (Smith, 1961c), adrenal cortex (Parkes, 1955), and thyroid (Parkes, 1959). It was important to allow sufficient time for the glycerol to permeate the tissue and to handle the tissue fragments carefully after thawing.

\section{PRESERVATION OF MORE COMPLEX TISSUES} None of the techniques described so far has been successful for the preservation of more complex tissues, much less of whole organs like heart, liver, and kidneys. The reasons for this failure are obscure, and various possibilities have been discussed in detail elsewhere (Pegg, 1973). However, an interesting technique has been developed by Farrant (1965) and Elford and Walter (1972) which may eventually make cryopreservation of quite complex tissues a reality. Farrant was studying possible mechanisms of freezing injury in smooth muscle tissue when he observed that greatly improved functional recovery could be obtained if the concentration of DMSO was increased during cooling and decreased during rewarming so that freezing was never allowed to take place. The changes in DMSO concentration were made in steps, sufficient time being allowed for diffusion through the tissue at each step. Elford and Walter (1972) found that function could be improved still further if the major anion in the medium had a molecular weight greater than 200 and if the initial $\mathrm{pH}$ of the medium, measured in the presence of $7.7 \mathrm{M}$ DMSO, exceeded $8 \cdot 4$. Reversing the relative concentrations of sodium and potassium in the bathing medium improved the speed of recovery after rewarming. Maximum recovery was obtained when medium containing $60 \mathrm{~mm}$ PIPES (piperazine-NN'-bis-2ethanesulphonate) and $165 \mathrm{~mm} \mathrm{~K}^{+}$was used; the DMSO concentration was increased in five stages at $37^{\circ} \mathrm{C},-7^{\circ} \mathrm{C},-14^{\circ} \mathrm{C},-22^{\circ} \mathrm{C}$, and $-39^{\circ} \mathrm{C}$, and

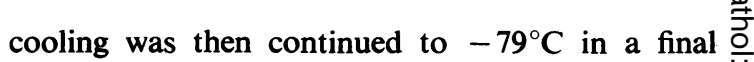
DMSO concentration of $7 \cdot 7 \mathrm{M}$. The steps were reversed during warming and there was no freezing $\stackrel{5}{\rightarrow}$ at any time. Contractile response to histamine was measured in an organ bath at $37^{\circ} \mathrm{C}$, and the transient response was as powerful as that of unfrozen muscle, although this was followed by a gradual relaxation $\triangle$ which was not seen in the controls. Electron micro- क scopic appearances were indistinguishable from those $\vec{O}$ of fresh muscle. In this technique there is no increase in electrolyte concentration although there are $\vec{\omega}$ changes in pH during cooling and, of course, in DMSO concentration. This technique is much more $\frac{?}{0}$ complicated to use than any of the more conventional iु methods described previously, but this may be acceptable in special circumstances; it is hoped, for example, that some success in subzero organ preservation may eventually be obtained in this way.

\section{Equipment for Cryopreservation}

Throughout this review emphasis has frequently $\vec{\theta}$ been laid on the importance of cooling rate, of $\sigma$ storage temperature, and, during two-step techniques, of the intermediate holding temperature. Several sophisticated controlled-rate cooling machines have been described (Pegg et al, 1973; Hayes et al, 1974) and some are commercially $\stackrel{\square}{\square}$ available; they are convenient to use and provide a $\stackrel{2}{\vec{F}}$ record of the cooling curve actually obtained, which is a valuable safeguard. All the machines currently on the market in the United Kingdom use liquid nitrogen as the refrigerant. Any potential purchaser should however ensure that a cam follower, or ? some similar programming device, is used: dif- $\frac{5}{3}$ ferential thermocouple controllers have serious drawbacks which are discussed elsewhere (Pegg et al, 1973) and their use is not recommended. It is quite possible however to build simple cooling apparatus in the laboratory, and devices that rely on the $\frac{D}{2}$ immersion of an insulated cooling vessel in a bath of liquid nitrogen or methylated spirit cooled with $N$ solid carbon dioxide are perfectly practicable. N Rather less satisfactory are the insulated hollow $\mathcal{N}$ plugs designed to produce slower cooling when $\mathrm{\omega}$ inserted into the neck of a liquid nitrogen tank; the cooling rates obtained are quite variable and very dependent on the load of samples being cooled.

The constant-temperature bath, typically at $-25^{\circ} \mathrm{C}$, required for two-step cooling is best provided by placing a bath of silicone oil or glycerol $\underset{\mathbb{D}}{\stackrel{D}{ }}$ solution in an electrical refrigerator set to that $\frac{\Omega}{\Phi}$ temperature.

Storage of cells is most conveniently and reliably achieved by the use of liquid nitrogen refrigerators. 8 There is a wide choice of refrigerators on the market 
offering liquid or gas-phase storage or both, in sizes varying from some 7 litres to 640 litres capacity, and with or without elaborate inventory control systems. Very small and unspillable refrigerators are also available for the transport of frozen samples. Where higher temperatures are satisfactory, reliable electrical refrigerators operating at $-80^{\circ} \mathrm{C}$ are available.

A list of manufacturers of specialist equipment is appended.

\section{References}

Ashwood-Smith, M. J. (1961). Preservation of mouse bone marrow at $-79^{\circ} \mathrm{C}$ with dimethyl sulphoxide. Nature (Lond.), 190, 1204-1205.

Ashwood-Smith, M. J. (1964). Low temperature preservation of mouse lymphocytes with dimethyl sulphoxide. Blood, 23, 494-501.

Baldini, M., Costea, N., and Dameshek, W. (1960). The viability of stored human platelets. Blood, 16, 1669-1692.

Barnes, D. W. H. and Loutit, J. F. (1955). The radiation recovery factor: preservation by the Polge-Smith-Parkes technique. J. nat. Cancer Inst., 15, 901-905.

Berg, van den L. (1959). The effect of addition of sodium and potassium chloride to the reciprocal system: $\mathrm{KH}_{2}, \mathbf{P O}_{4}-$ $\mathrm{Na}_{2}, \mathrm{HPO}_{4}-\mathrm{H}_{2} \mathrm{O}$ on $\mathrm{pH}$ and composition during freezing. Arch. Biochem., 84, 305-315.

Berg, van den, L. and Rose D. (1959). Effect of freezing on the $\mathrm{pH}$ and composition of sodium and potassium phosphate solutions: the reciprocal system $\mathrm{KH}_{2} \mathrm{PO}_{4}-\mathrm{Na}_{2}$, $\mathrm{HPO}_{4}-\mathrm{H}_{2} \mathrm{O}$. Arch Biochem., 81, 319-329.

Billingham, R. E. and Medawar, P. B. (1952). The freezing, drying and storage of mammalian skin. J. exp. Biol., 29, 454-468.

Bradley, T. R. and Metcalf, D. (1966). The growth of mouse bone marrow cells in vitro. Aust. J, exp. Biol. med. Sci., 44, 287-299.

Bricka, M. and Bessis, M. (1955). Sur la conservation des érythrocytes par congélation à basse temperature en présence de polyvinyl-pyrrolidone et de dextran. C.R. Soc. Biol. (Paris), 149, 875-877.

Bronson, W. R. and McGinniss, M. H. (1962). The preservation of human red blood cell agglutinogens in liquid nitrogen: study of a technic suitable for routine blood banking. Blood, 20, 478-484.

Callow, L. L. and Farrant, J. (1973). Cryopreservation of the promastigote form of Leishmania tropica var. Major at different cooling rates. Int. J. Parasit., 3, 77-88.

Cavins, J. A., Djerassi, I., Aghai, E., and Roy, A. J. (1968). Current methods for the cryopreservation of human leukocytes (granulocytes). Cryobiology, 5, 60-69.

Cavins, J. A., Djerassi, I., Roy, A. J., and Klein, E. (1965). Preservation of viable human granulocytes at low temperatures in dimethyl sulphoxide. Cryobiology, 2, 129-133.

Cavins, J. A., Scheer, S. C., Thomas, E. D., and Ferrebee, J. W. (1964). The recovery of lethally irradiated dogs given infusions of autologous leukocytes preserved at $-80^{\circ} \mathrm{C}$. Blood, 23, 38-43.

Cohen, P. and Gardner, F. H. (1966). Platelet preservation. IV. Preservation of human platelet concentrates by controlled slow freezing in a glycerol medium. New Engl. J. Med., 274, 1400-1407.

Collins, W. E. and Jeffery, G. M. (1963). The use of dimethyl sulphoxide in the low-temperature frozen preservation of experimental malarias. J. Parasit., 49, 524-525.

Daw, A., Farrant, J., and Morris, G. J. (1973). Membrane leakage of solutes after thermal shock or freezing. Cryobiology, 10, 126-133.
Diller, K. R., Cravalho, E. G., and Huggins, C. E. (1972). Intracellular freezing in biomaterials. Cryobiology, 9, 429-440.

Djerassi, I. and Roy, A. (1963). A method for preservation of viable platelets: combined effects of sugars and dimethylsulphoxide. Blood, 22, 703-717.

Dougherty, R. M. (1962). Use of dimethyl sulphoxide for preservation of tissue culture cells by freezing. Nature (Lond.), 193, 550-552.

Elford, B. C. and Walter, C. A. (1972). Effects of electrolyte composition and $\mathrm{pH}$ on the structure and function of smooth muscle cooled to $-79^{\circ} \mathrm{C}$ in unfrozen media. Cryobiology, 9, 82-100.

Farrant, J. (1965). Mechanism of cell damage during freezing and thawing and its prevention. Nature (Lond.), 205, 1284-1287.

Farrant, J., Knight, S. C., McGann, L. E., and O'Brien, J. (1974). Optimal recovery of lymphocytes and tissue culture cells following rapid cooling. Nature (Lond.), 249, 452453.

Farrant, J., Knight, S. C., and Morris, G. J. (1972). Use of different cooling rates during freezing to separate populations of human peripheral blood lymphocytes. Cryobiology, 9, 516-525.

Farrant, J., Knight, S. C., O'Brien, J. A., and Morris, G. J. (1973). Selection of leukaemic cell populations by freezing and thawing. Nature (Lond.), 245, 322-323.

Farrant, J. and Morris, G. J. (1973). Thermal shock and dilution shock as the causes of freezing injury. Cryobiology, 10, 134-140.

Farrant, J. and Woolgar, A. E. (1970). Possible relationships between the physical properties of solutions and cell damage during freezing. In The Frozen Cell: $A$ Ciba Foundation Symposium, edited by G. E. W. Wolstenholme and M. O'Connor, pp 97-119. Churchill, London.

Farrant, J. and Woolgar, A. E. (1972a). Human red cells under hypertonic conditions: a model system for investigating freezing damage. 1. Sodium chloride. Cryobiology, 9, 9-15.

Farrant, J. and Woolgar, A. E. (1972b). Human red cells under hypertonic conditions: a model system for investigating freezing damage. 2. Sucrose. Cryobiology, 9, 16-21.

Fry, R. M. (1966). Freezing and drying of bacteria. In Cryobiology, edited by H. T. Meryman, pp. 665-696. Academic Press, London and New York.

Greaves, R. I. N. (1956). The preservation of bacteria Canad. J. Microbiol., 2, 365-371.

Greenberg, S. (1966). Use of dimethyl sulfoxide to prevent damage to leukemic cells in freezing. N.Y. St.J. Med., 66, 652-654.

Grieff, D. and Rightsel, W. (1966). Freezing and freezedrying of viruses. In Cryobiology, edited by H. T. Meryman, pp. 697-728. Academic Press, London and New York.

Gye, W. E., Begg, A. M., Mann, I., and Craigie, J. (1949). The survival of activity of mouse sarcoma tissue after freezing and drying. Brit. J. Cancer, 3, 259-267.

Handin, R. I. and Valeri, C. R. (1972). Improved viability of previously frozen platelets. Blood, 40, 509-513.

Hauschka, T. S., Mitchell, J. T., and Niederpruem, D. J. (1959). A reliable frozen tissue bank: viability and stability of 82 neoplastic and normal cell types after prolonged storage at $-78^{\circ} \mathrm{C}$. Cancer Res., 19, 643-653.

Hayes, A. R., Pegg, D. E., and Kingston, R. E. (1974). A multirate small-volume cooling machine. Cryobiology, 11, 371-377.

Huggins, C. E. (1963). Preservation of blood for transfusions by freezing with dimethylsulfoxide and a novel washing technique. Surgery, 54, 191-194. 
Huntsman, R. G., Hurn, B. A. L., and Lehmann, H. (1960). Storage of red cells for blood-grouping after freezing in liquid nitrogen. Brit. med. J., 2, 118.

Iossifides, I., Geisler, P., Eichman, M. F., and Tocantins, L. M. (1963). Preservation of the clot-retracting activity of platelets by freezing in dimethylsulfoxide and plasma. Transfusion, 3, 167-172.

Ising, U. (1960). Chromosomal pattern in some mouse ascites tumours after deep freezing. Exp. Cell Res., 19, 475-488.

Jellinek, H. H. G. and Fok, S. Y. (1967). Freezing of aqueous polyvinylpyrrolidone solutions. Kolloidzeitschrift, 220, 122-133.

Knight, S. C., Farrant, J., and O'Brien, J. (1975). In defence of granulocyte preservers. Lancet, 1, 929. (Letter.)

Kurnick, N. B. (1968). The present status of low-temperature preservation of bone marrow. Proceedings of the 11th Congress of the International Society of Blood Transfusion, Sydney, 1966 (Bibliotheca haematologica, No. 29), edited by L. Holländer, Part 3, pp. 788-796. Karger, Basle and New York.

Leaf, A. (1959). Maintenance of concentration gradients and regulation of cell volume. Ann. N.Y. Acad. Sci., 72, 396404.

Lee, D. and Allen, C. (1972). The effect of increasing concentrations of potassium chloride on rat liver lysosomes. Biochem. J., 128, 142P.

Lehr, H. B., Berggren, R. B., Lotke, P. A., and Coriell, L. L. (1964). Permanent survival of preserved skin autografts. Surgery, 56, 742-746.

Leibo, S. P., Farrant, J., Mazur, P., Hanna, M. G., and Smith, L. H. (1969). Effects of freezing on marrow stem cell suspensions: interactions of cooling and warming rates in the presence of PVP, sucrose or glycerol. Cryobiology, 6, 315-332.

Lovelock, J. E. (1953a). The haemolysis of human red bloodcells by freezing and thawing. Biochim. biophys. Acta, 10, 414-426.

Lovelock, J. E. (1953b). The mechanism of the protective action of glycerol against haemolysis by freezing and thawing. Biochim. biophys. Acta, 11, 28-36.

Lovelock, J. E. (1955). Haemolysis by thermal shock. Brit. J. Haemat., 1, 117-129.

Lowenthal, R. M., Grossman, L., Goldman, J. M., Storring, R. A., Buskard, N. A., Park, D. S., Murphy, B. C., Spiers, A. S. D., and Galton, D. A. G. (1975). Granulocyte transfusions in treatment of infections in patients with acute leukaemia and aplastic anaemia. Lancet, 1, 353-358.

Luyet, B. J. and Keane, J., Jr. (1955). A critical temperature range apparently characterised by sensitivity of bull semen to high freezing velocity. Biodynamica, 7, 281-292.

Lyons, J. M. (1972). Phase transitions and control of cellular metabolism at low temperatures. Cryobiology, 9, 341-350.

McEntegart, M. G. (1954). Prolonged survival of Trichomonas vaginalis at $-79^{\circ} \mathrm{C}$. Nature (Lond.), 183, 270-271.

Mazur, P. (1963). Kinetics of water loss from cells at subzero temperatures and the likelihood of intracellular freezing. J. gen. Physiol., 47, 347-369.

Mazur, P., Farrant, J., Leibo, S. P., and Chu, E. H. Y. (1969). Survival of hamster tissue culture cells after freezing and thawing: interactions between protective solutes and cooling and warming rates. Cryobiology, 6, 1-9.

Mazur, P., Leibo, S. P., Farrant, J., Chu, E. H. Y., Hanna, M. G., Jr., and Smith, L. H. (1970). Interactions of cooling rate, warming rate, and protective additive on the survival of frozen mammalian cells. In The Frozen Cell: A Ciba Foundation Symposium, edited by G. E. W. Wolstenholme and M. O'Connor, pp. 69-88. Churchill,
London.

Mazur, P., Rhian, M. A., and Mahlandt, B. G. (1957). Survival of Pasteurella tularensis in sugar solutions after $\overline{\bar{A}}$ cooling and warming at sub-zero temperatures. $J$. Bact., 73, 394-397.

Melnick, J. L. (1965). Preservation of viruses by freezing Fed. Proc., 24, Suppl. 15, S280-S283.

Meryman, H. T. (1968). Modified model for the mechanism of freezing injury in erythrocytes. Nature (Lond.), 218, 333-336.

Meryman, H. T. and Kafig, E. (1955). Rapid freezing and thawing of whole blood. Proc. Soc. exp. Biol. N.Y., 90, 9 587-589.

Meynell, G. G. (1958). The effect of sudden chilling on $\vec{\omega}$ Escherichia coli. J. gen. Microbiol., 19, 380-389.

Mieth, H. (1966). Tiefgefrierkonservierung verschiedener응 Blut- und Gewebeprotozoen in flüssigem Stickstoff. $Z$. i్ Tropenmed. und Parasit., 17, 103-108.

Morris, G. J., Buckland, R., Rubenstein, D., and Farrant, J. $\rightarrow$ (1973). Preservation of human tracheal organ cultures at $\mathrm{N}$ $-196^{\circ}$ C. J. med. Microbiol., 6, 123-126.

Muggleton, P. W. (1960). Freeze-drying of bacteria with 윽 special reference to BCG. In Recent Research in Freezing and Drying, edited by A. S. Parkes and A. U. Smith, pp. 229-237. Blackwell, Oxford.

Murphy, S., Sayar, S. N., Abdou, N. L., and Gardner, F. H. (1974). Platelet preservation by freezing. Use of dimethyl $\overrightarrow{0}$ sulphoxide as cryoprotective agent. Transfusion, 14, 139- హ్ 144.

Nash, T. (1962). The chemical constitution of compounds which protect erythrocytes against freezing damage. J.O gen. Physiol., 46, 167-175.

O'Neill, P., Mueller, F. O., and Trevor-Roper, P. D. (1967). On the preservation of cornea at $-196^{\circ} \mathrm{C}$ for full-thickness homografts in man and dog. Brit. J. Ophthal., 51, 13-30.

Parkes, A. S. (1955). Viability of adrenocortical tissue transplanted after freezing and thawing. Proc. roy. Soc. B.,음 144, 314-328.

Parkes, A. S. (1959). Functional grafts of fresh or stored thyroid tissue. J. Endocr., 18, xxxv-xxxvi.

Pegg, D. E. (1964a). Freezing of bone marrow for clinical use Cryobiology, 1, 64-71.

Pegg, D. E. (1964b). In vitro assessment of cell viability in: human bone marrow preserved at $-79^{\circ} \mathrm{C}$.J. appl. Physiol., 19, 123-126.

Pegg, D. E. (1964c). Cytology of human bone marrowo subjected to prolonged storage at $-79^{\circ} \mathrm{C}$.J. appl. Physiol., 19, 301-309.

Pegg, D. E. (1973). Theory and experiments towards sub 윽 zero organ preservation. In Organ Preservation, edited by D. E. Pegg, pp. 108-122. Churchill-Livingstone, Edinburghㅡ. and London.

Pegg, D. E., Hayes, A. R., and Kingston, R. E. (1973). Cooling equipment for use in cryopreservation. Cryo- $\mathrm{N}$ biology, 10, 271-281.

Pegg, P. J. (1965). The preservation of leucocytes for cytogenetic and cytochemical studies. Brit. J. Haemat., 11 , 586-591.

Persidsky, M. D., Richards, V., and Leef, J. (1965). Cryo읃 preservation of bone marrow with low molecular weight polyvinylpyrrolidone. Cryobiology, 2, 74-78.

Polge, C. and Lovelock, J. E. (1952). Preservation of bulto semen at $-79^{\circ} \mathrm{C}$. Vet. Rec., 64, 396-397.

Polge, C., Smith, A. U., and Parkes, A. S. (1949). Reviva店 of spermatozoa after vitrification and dehydration at low temperatures. Nature (Lond.), 164, 666.

Polge, C. and Soltys, M. A. (1957). Preservation of trypano $\sigma$ somes in the frozen state. Trans. R. Soc. trop. Med. Hyg., 51, 519-526.

Porterfield, J. S. and Ashwood-Smith, M. J. (1962). Preserfy 
vation of cells in tissue culture by glycerol and dimethyl sulphoxide. Nature (Lond.), 193, 548-550.

Postgate, J. R. and Hunter, J. R. (1961). On the survival of frozen bacteria. J. gen. Microbiol., 26, 367-378.

Putten, L. M. van (1965). Quantitative aspects of the storage of bone marrow cells for transplantation. Europ. J. Cancer, 1, 15-22.

Pyle, H. M. (1964). Glycerol preservation of red blood cells. Cryobiology, 1, 57-60.

Rowe, A. W. (1974). A 'cookbook' for low glycerol rapid freezing. Lab. Manage., 20-30.

Scherer, W. F. (1960). Effects of freezing speed and glycerol diluent on 4-5 year survival of the HeLa and L cells. Exp. Cell Res., 19, 175-176.

Scott, W. J. (1960). In Recent Rescarch in Freezing and Drying, edited by A. S. Parkes and A. U. Smith, p. 188. Blackwell, Oxford.

Smith, A. U. (1952). Cultivation of ovarian granulosa cells after cooling to very low temperatures. Exp. Cell Res., 3, 574-583.

Smith, A. U. (1961a). Biological Effects of Freezing and Supercooling,p. 440. Edward Arnold, London. Williams and Wilkins, Baltimore.

Smith, A. U. (1961b). Biological Effects of Freezing and Supercooling. Edward Arnold, London. Williams and Wilkins, Baltimore.

Smith, A. U. (1961c). Biological Effects of Freezing and Supercooling, p. 157. Edward Arnold, London. Williams and Wilkins, Baltimore.

Smith, E. R., Hadidian, Z., and Mason, M. M. (1967). The single- and repeated-dose toxicity of dimethyl sulphoxide. Ann. N. Y. Acad. Sci., 141, 96-109.

Strumia, M. M., Colwell, L. S., and Strumia, P. V. (1960). Preservation of blood for transfusion. IV. In vitro recovery after freezing and thawing of red cells modified with sugars. V. Post-transfusion of red cells modified with sugars, frozen, and stored in the frozen state. J. Lab. clin. Med., 56, 576-593.

Thorp:, P. E., Knight, S. C., and Farrant, J. (1975). Optimal conditions for the preservation of mouse lymph node cells in liquid nitrogen using cooling rate techniques. Cryobiology, 12, (in press).

Valeri, C. R., Feingold, H., and Marchionni, L. D. (1974) A simple method for freezing human platelets using $6 \%$ dimethylsulphoxide and storage at $-80^{\circ} \mathrm{C}$. Blood, 43, 131-136.

Vallejos, C., McCredie, K. B., Bodey, G. P., Hester, J. P., and Freireich, E. J. (1975). White blood cell transfusions for control of infections in neutropenic patients. Transfusion, 15, 28-33.

Walter, C. A., Knight, S. C., and Farrant, J. (1975). Ultrastructural appearance of freeze-substituted lymphocytes frozen by interrupting rapid cooling with a period at $-26^{\circ} \mathrm{C}$. Cryobiology, 12, 103-109.

Weiner, W. (1961). Reconstitution of frozen red cells. Lancet, $1,1264-1265$.

Whittingham, D. G., Leibo, S. P., and Mazur, P. (1972). Survival of mouse embryos frozen to $-196^{\circ} \mathrm{C}$ and $-269^{\circ} \mathrm{C}$. Science, 178, 411-414.

Wilmut, I. (1972). The effect of cooling rate, warming rate, cryoprotective agent, and stage of development on survival of mouse embryos during freezing and thawing. Life Sci., 11, 1071-1079.

Woodburn, M. J. and Strong, D. H. (1960). Survival of Salmonella typhimurium, Staphylococcus aureus, and Streptococcus faecalis frozen in simplified food substrates. Appl. Microbiol., 8, 109-113.

Woolgar, A. E. (1972). A study of the effects of freezing on human red blood cells. PhD Thesis. Council for National Academic Awards.

\section{Appendix}

SUPPLIERS OF CRYOPRESERVATION EQUIPMENT

Cooling apparatus

Dewar flasks

Electrical refrigerators

Liquid nitrogen refrigerators and liquefied gas containers

Freeze driers
Planar Products Ltd, Windmill Rd, Sunbury on Thames, Middlesex

Cryoson,

UK Agent-Cryotech, PO Box 16,

Wallingford, Oxon.

Union Carbide (UK) Ltd 8 Grafton St, London W1A 2LR

Day-Impex Ltd, Station Works, Earls Colne, Colchester, Essex

Boro Labs Ltd,

Paices Hill,

Aldermaston, Berks.

Lec Refrigeration Ltd,

Bognor Regis, Sussex

Union Carbide (UK) Ltd,

8 Grafton St,

London W1A 2LR

British Oxygen

Cryoproducts,

Manor Royal,

Crawley, Sussex

Edwards High Vacuum,

Manor Royal,

Crawley, Sussex

Vertis, UK Agent,

Techmation Ltd,

58 Edgware Way,

Edgware,

Middlesex HA8 8JP 